\title{
The status and conservation of threatened birds in the Upper Guinea forest
}

\author{
GARY ALLPORT
}

\section{Summary}

There are twenty-one endemic and near-endemic forest birds in the Upper Guinea forest of West Africa. Less than $80,000 \mathrm{~km}^{2}$ of their habitat remains and this is being rapidly degraded and fragmented. Eight threatened and two near-threatened birds were identified by Collar and Stuart (1985) in this region based on the scant information then available. More recent surveys confirm the threatened status of all these birds, but two species, Melaenornis annamarulae and Malimbus ballmanni, should now be considered Vulnerable having previously been placed in the Indeterminate category. Phyllastrephus leucolepis, described since the production of the Red Data Book, is only found in the forest of east Liberia and must be considered Endangered. Records suggest that all three species are restricted to the western part of the Upper Guinea forest. There are two forest areas which are of the highest priority for the conservation of these and the other endemic birds: (i) south-east Liberia/south-west Ivory Coast; (ii) south-east Sierra Leone/northwest Liberia.Ceratogymnasubcylindricus and Phyllastrepinus baumanni are recommended for inclusion in the Near-threatened category.

Vingt-et-une espèces forestières d'oiseaux endémiques ou quasiment endémiques vivent dans la forêt de Haute-Guinée en Afrique de l'Ouest. A l'époque actuelle leur habitat, qui fût déjà réduit à moins de $80,000 \mathrm{~km}^{2}$, continue d'être rapidement dégradé et fragmenté. Collar et Stuart (1985) identifièrent huit espèces menacées plus deux espèces probablement menacées pour la région, basé sur le peu d'information disponible à l'époque. Des investigations plus récentes confirment le statut de toutes ces espèces sauf deux, Melaenornis annamarulae et Malimbus ballmanni, qui fûrent insuffisamment connus, doivent maintenant être considérés vulnérables. Phyllastrephus leucolepis ne fût décrit pour la science qu'après la production du livre rouge et ne se trouve uniquement dans la forêt du Libéria oriental, et doît donc être considéré comme en danger. Des observations suggèrent que toutes ces espèces soient limitées à la partie occidentale de la forêt de HauteGuinée. Deux régions forestières se révèlent d'être de la plus haute priorité pour la sauvegarde de ces éspèces et des autres oiseaux endêmiques: (i) le sud-est du Libéria/sudouest de la Côte-d'Ivoire et (ii) le sud-est du Sierra Léone/nord-ouest du Libéria. Nous recommandons d'inclure Ceratogymna subcylindricus et Phyllastrephus baumanni dans la catégorie probablement menacé.

\section{Introduction}

One of the regions highlighted by the ICBP Red Data Book (Collar and Stuart 1985), and latterly the ICBP inventory of key forests in Africa (Collar and Stuart 1988), is the area of forest lying west of the dry coastal grasslands of the "Dahomey Gap" in West Africa - the Upper Guinea forest (Figure 1 ). At the time of publication of the Red Data Book little recent ornithological work had been 


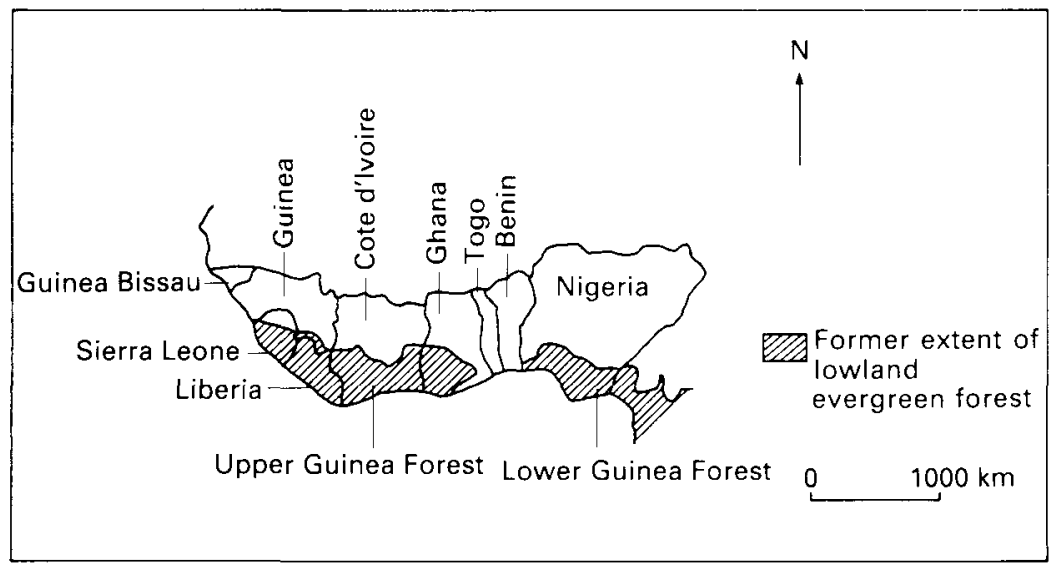

Figure 1. The location of the West African nations and the former extent of the Upper Guinea forest block.

undertaken in this region and consequently data on the frequency and distribution of threatened species were scarce. As a direct result of the ICBP publications the spotlight of ornithological concern was cast upon the area and a number of conservation initiatives resulted. The aim of this paper is to update the status assessments and prospects for conservation of the endemic and threatened forest birds of the region in the light of the findings of recent work. The species accounts presented here should be seen as supplements to those in the Red Data Book and include only data collected after the production of that work in 1985.

Five countries are custodians of the main Upper Guinea block with a small outlying fragment in Togo (Figure 1). White (1983) identified four types of closed-canopy forest within the region according to climate (Figure 2). The exact area of remaining natural forest is debatable, but data from a range of sources suggests that $c .77 \%$ of the original forest area has been destroyed (Appendix 1 ). A recent analysis of satellite imagery perhaps portrays a more optimistic picture (Figure 3, Päivinen and Witt 1989). The major causes of forest loss have been logging, agricultural encroachment and mining. The rate of destruction was estimated at $>2 \%$ per annum in Ivory Coast and Ghana (Poore et al. 1989), and $1.9 \%$ per annum in Liberia prior to the recent conflict (Poore et al. 1989, S. Anstey pers. comm. 1990). Habitat destruction has been so widespread that large contiguous blocks of forest capable of supporting individual populations of particular species are very restricted and mostly within protected areas. Two major blocks of forest remain. The first and largest is in south-east Liberia and south-west Ivory Coast which includes Taï National Park and the N'zo Fauna Reserve in Ivory Coast, and in Liberia, the Grebo, Gio and Krahn-Bassa National Forests and Sapo National Park. This part of Liberia contains the majority of the remaining unprotected Upper Guinean forest (Figure 3; S. Anstey pers. comm. 1990). The second extensive area lies in south-eastern Sierra Leone and northwest Liberia encompassing the Gola Forest Reserves in the former country and the Gola-Kpelle-Belle National Forests in the latter state.

The locations of many of the protected areas are detailed in Mackinnon and Mackinnon (1986) and a set of sites of proven bird conservation value have been 


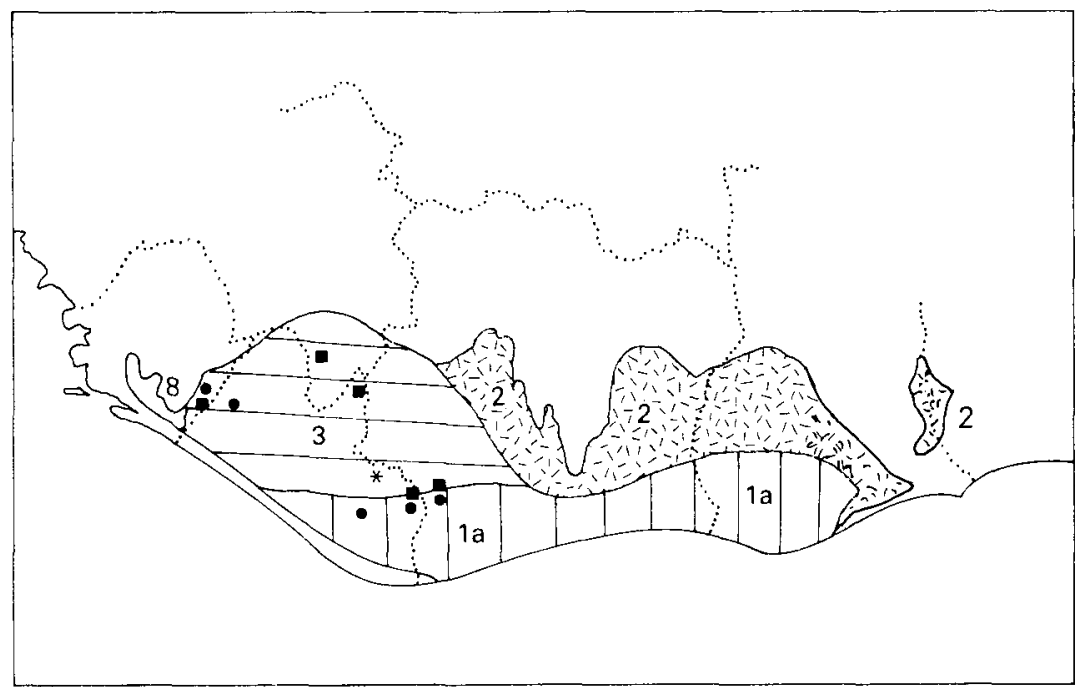

Figure 2. Forest-types in Upper Guinea (from White 1.983) and the locations of sightings of the "western" endemics. Forest-types: 1a, wetter guineo-congolian forest; 2 , drier guineo-congolian forest; 3 , patchwork of 1 a and $2 ; 8$, swamp forest; filled squares, Nimba Flycatcher; filled circles, Gola Malimbe; asterisk, Spot-winged Greenbul. National borders are indicated by dotted lines.

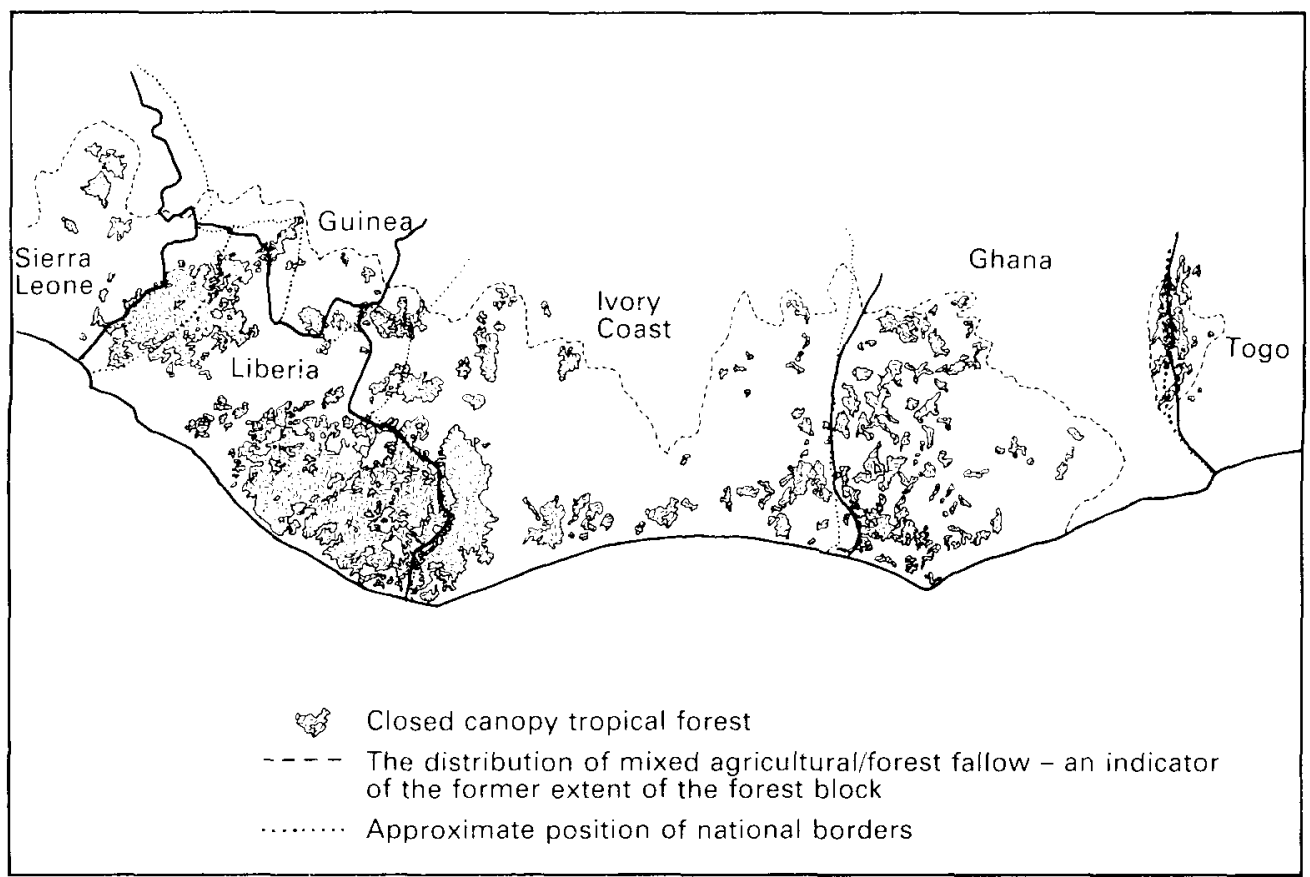

Figure 3. The distribution of closed-canopy tropical forest in West Africa (Päivinen and Witt 1989, WCMC/IUCN in prep.). 
identified by ICBP (Collar and Stuart 1988). However, certain sites in Liberia have not yet achieved the recognition that they deserve considering the proportion of the remaining habitat that they contain, most notably the large KrahnBassa National Forest and the contiguous Gola-Kpelle-Belle National Forests (Figure 4).

The qualification of a particular species for threatened status is determined by the extent of its range and the perceived response of that species to variations in habitat quality. Thus a very threatened species in the Upper Guinea would have a limited distribution within the region, be only found in primary forest and be very sensitive to man's activities such as hunting. A less threatened species might be of similar distribution but occur at a high density and be capable of maintaining its population in a range of altered habitats.

Since the wildlife of the Upper Guinea forest is being threatened directly by habitat clearance, and indirectly by fragmentation and consequent non-viability of individual populations (Gilpin and Soulé 1986), any forest-dwelling species endemic or near-endemic to the region is potentially threatened. There are 21 such bird species (Table 1). Fifty-four birds of the Upper Guinea forest were seriously considered for inclusion in the "threatened" and "near-threatened" categories of the Red Data Book (Appendix 2). Of these "candidate" species, nine were considered threatened and five near-threatened by the authors. Although the 40 candidate species remaining were not judged to be immediately threatened, many were considered sensitive enough to warrant future monitoring. All of the birds included in the threatened and near-threatened categories

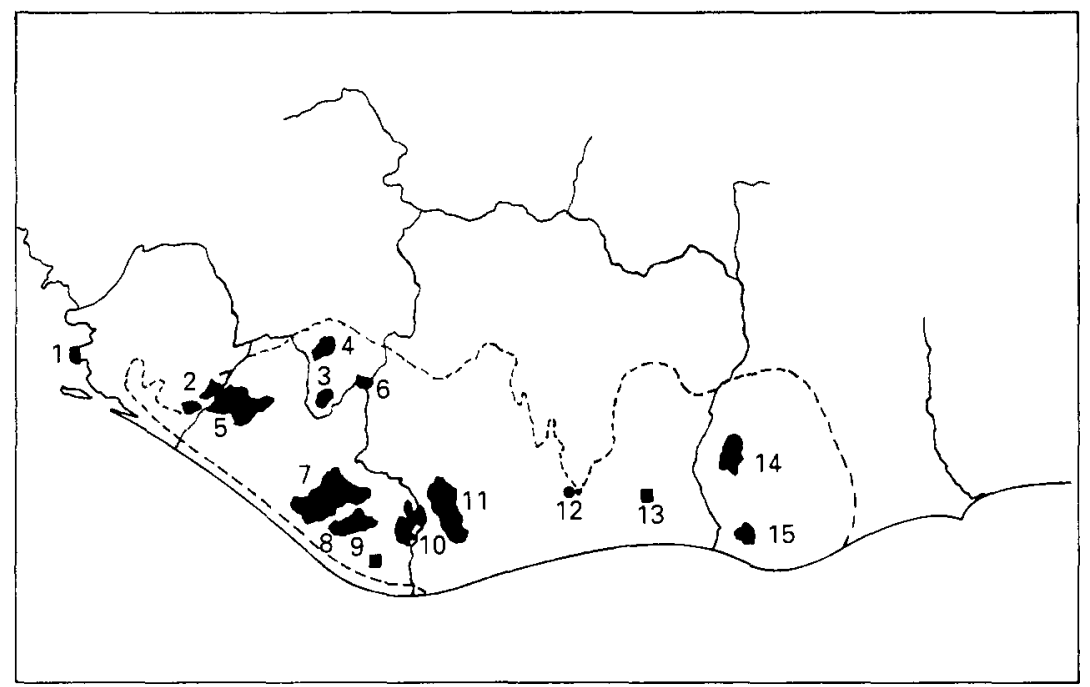

Figure 4. The former extent of the closed-canopy forest block in the Upper Guinea region (dashed line) (White 1983). The location of the main sites referred to in the text and Table 3: 1, Freetown Peninsula or Western Area forests, Sierra Leone; 2, Gola forests, Sierra Leone; 3, Diecké Forest, Guinea; 4, Massif du Ziama, Guinea; 5, Gola-Kpelle-Belle (LofaMano), Liberia; 6, Nimba, Liberia-Guinea-Ivory Coast; 7, Krahn-Bassa, Liberia; 8, Sapo, Liberia; 9, Barrobo, Liberia; 10, Grebo Forest, Liberia; 11, Taï Forest, Ivory Coast; 12, Lamto, Ivory Coast; 13, Yapo, Ivory Coast; 14, Bia, Ghana; 15, Nini-Suhien, Ghana. National borders are indicated by solid lines. 
Table 1. Rare and restricted forest birds of the Upper Guinea region

\begin{tabular}{|c|c|c|c|c|c|c|}
\hline \multirow[b]{2}{*}{ Species } & \multirow[b]{2}{*}{ Dist } & \multirow[b]{2}{*}{ RDB } & \multicolumn{3}{|c|}{ Habitat } & \multirow[b]{2}{*}{ Hunt } \\
\hline & & & Pri & $\log$ & Fbsh & \\
\hline White-breasted Guineafowl & UG & $* * * * *$ & ++ & + & - & ++ \\
\hline Yellow-casqued Hornbill & UG(SWN, Ca) & + & +++ & ++ & + & + \\
\hline Brown-cheeked Hornbill & UG & + & ++ & ++ & - & + \\
\hline Rufous Fishing Owl & UG & $* *$ & $\mathrm{R}$ & - & - & + \\
\hline Yellow-footed Honeyguide & $\mathrm{G}-\mathrm{C}$ & * & + & - & - & - \\
\hline Golden-backed Woodpecker & $\mathrm{UG}(\mathrm{Ca})$ & + & + & + & + & - \\
\hline Fire-bellied Woodpecker & UG(SWN) & & ++ & ++ & + & - \\
\hline Rufous-winged Illadopsis & UG & ++ & +++ & ++ & + & - \\
\hline Yellow-throated Olive Greenbul & $\mathrm{UG}(\mathrm{Ca})$ & $* * * *$ & ++ & + & - & - \\
\hline Grey-headed Bristlebill & UG(SWN, Ca) & & +++ & +++ & +++ & - \\
\hline Baumann's Greenbul & UG(SWN) & & + & + & - & - \\
\hline Spot-winged Greenbul & $w U G$ & $?$ & + & - & - & - \\
\hline Finsch's Rusty Thrush & UG(SWN) & & ++ & ++ & ++ & - \\
\hline Ussher's Dusky Flycatcher & UG & + & + & ++ & ++ & - \\
\hline Nimba Flycatcher & $w U G$ & $* * *$ & + & - & - & - \\
\hline Sharpe's Apalis & UG & + & ++ & ++ & + & - \\
\hline Western Wattled Cuckoo-shrike & UG & $* * * *$ & + & + & - & - \\
\hline Copper-tailed Glossy Starling & UG & ++ & + & +++ & ++ & - \\
\hline White-necked Picathartes & $\mathrm{UG}$ & $* * * *$ & + & + & - & + \\
\hline Buff-throated Sunbird & UG(SWN) & & + & + & ++ & - \\
\hline Gola Malimbe & wUG & $* * *$ & + & + & - & - \\
\hline
\end{tabular}

DIST, distribution.

Endemic: UG, Upper Guinea only; wUG, western Upper Guinea.

Near-endemic: UG(SWN), Upper Guinea and south-west Nigeria; UG(Ca), Upper Guinea and Casamance, Senegal.

Wider range: G-C, Guinea-Congolian.

RDB, Red Data Book Status (Collar and Stuart 1985).

+ , candidate; ++ , near-threatened; ${ }^{*}$, insufficiently known; ${ }^{* *}$, rare; ${ }^{* * *}$, indeterminate; ${ }^{* * *}$, vulnerable; ${ }^{* * * *}$, endangered; ?, undescribed at the time of the completion of the Red Data Book.

HABITAT: Pri, pristine forest; Log, logged forest; Fbsh, farmbush; R, riverine within habitat.

+++ , common; ++ , moderately common; + , rare; - , absent.

HUNT, sensitivity to hunting or collecting

++ , high sensitivity; + , low sensitivity; - , not taken.

(The treatment of both Brown-cheeked Hornbill and Baumann's Greenbul as full species is debatable, but from a conservation perspective it is prudent to treat them as such until conclusive evidence suggests otherwise.)

and ten of the candidate species are regionally endemic or near-endemic (Table 1, Appendix 2). However, a number of the candidate species are not wholly forest-dependent (Appendix 2) including three that are near-threatened: Whiteeyed Prinia, Black-faced Stream Warbler and Turati's Boubou.

\section{Species accounts}

The threatened species categorisation given on the first line of each account has been reconsidered in the light of modern information and revised where appropriate. 
Distribution Recorded in the Upper Guinea forest from Sierra Leone to Ghana. Ghana: in the Western Region recent records from Nini-Suhien National Park and the adjacent Ankasa Game Production Reserve, Tano-Anwai and Boin-Tano Forest Reserves and mineral concession forests near Enchi, plus a single record from the west of Eastern region; may well be extinct outside of these sites in the extreme south-west (Grimes 1987, Dutson and Branscombe in prep., Taylor ms). Ivory Coast: the only recent records are from Taï, despite searches in a number of forests elsewhere in the country (Balchin 1988, Gartshore 1989, L. D. C. Fishpool pers. comm. 1990, M. E. Gartshore pers. comm. 1990). Liberia: recorded in Nimba, Sapo, Grebo and the forests of Grand Gedeh County (Gatter et al. 1988, Taylor 1988, S. Anstey pers. comm. 1990). Sierra Leone: recent records from Gola (Allport et al. 1989). Guinea: probably present on the Guinean side of Nimba but there are no records (Gatter et al. 1988).

Population The population is very fragmented but recent evidence suggests the species is moderately common in undisturbed primary habitat. In a $10-12 \mathrm{~km}^{2}$ protected area around the forest station in Taï, guineafowl were estimated at 1012 birds $/ \mathrm{km}^{2}$ (M. E. Gartshore pers. comm. 1990). Similar density estimates of 10-15 birds $/ \mathrm{km}^{2}$ for Gola suggest populations of $c .4,800$ and c.2,300 birds for the two forest reserves there (Allport $e t$ al. 1989). It is clearly sensitive to hunting and this may be why it is extremely rare in most areas. In the Gola region, where it is uneconomic to hunt this species, it probably occurs at a near-normal density, and it is similarly frequent in those areas of Taï which are free of hunting. However, it is very rare at all other sites including the largest areas of remaining forest in south-eastern Liberia (Carter 1987, Taylor 1988).

Ecology The species is found only in forest, principally in pristine habitat; there are now a handful of records from secondary and damaged areas (Davies 1987, Allport et al. 1989, Taylor ms), but it appears not to thrive in such conditions. There is some evidence of dispersal since two single birds were seen one year apart in a fragment of secondary forest on the periphery of Gola (Davies 1987).

Birds readily form groups which are probably exclusive and territorial, normally of up to 30 birds, comprising as many as three families with chicks and other adults: group formation may be seasonal (Table 2), possibly linked with

Table 2. Sizes of groups of White-breasted Guineafowl over a six-month period in Tail and Gola (Allport et al. 1989, Gartshore 1989).

\begin{tabular}{|c|c|c|c|c|c|}
\hline \multirow[b]{2}{*}{ Month } & \multicolumn{3}{|c|}{ Number of records } & \multirow[b]{2}{*}{ (Flock sizes) } & \multirow[b]{2}{*}{ Total } \\
\hline & Singles & Pairs & Groups & & \\
\hline November & 5 & 1 & 4 & $(4,5,5,12)$ & 10 \\
\hline December & 4 & 2 & 7 & $(2+, 4,5,6,14, c .6, c .20)$ & 13 \\
\hline January & o & 1 & 5 & $(2+, 4,6,9)$ & 6 \\
\hline February & o & o & 7 & $\left(2+, 3,3,4,4^{+}, 4^{+}, 5\right)$ & 7 \\
\hline March & o & o & 2 & $(6,20)$ & 2 \\
\hline April & $o$ & o & 6 & $(3,8,9,10,17,20)$ & 6 \\
\hline
\end{tabular}


breeding. Breeding records range over seven months: downy chicks have been seen in November (Nimba), December (Gola and Tai), January (Nimba), February (Tai), March and April (Nimba), and May (Tai) (Balchin 1988, Gatter et al. 1988, Allport et al. 1989, Gartshore 1989, Hoiting pers. comm. to M. E. Gartshore 1989, M. E. Gartshore pers. comm. 1990). This species can occur in mixed groups with Crested Guineafowl Guttera edouardi, but observations of such usually involve single White-breasted Guineafowl and so may just refer to odd individuals (Taylor ms). Large groups of White-breasted Guineafowl are normally monospecific. Crested Guineafowl is normally more frequent in secondary habitats. When disturbed the groups form up into tighter formation, cheeping loudly, and if the threat persists the group explodes into the canopy and scatters. A loud series of descending whistles is then given by females as the group reforms (Bechinger 1964, Allport et al. 1989). A loud trumpeting call has also been reported, delivered by a perching bird in the evening (A. G. Davies pers. comm. 1988, Kingdon 1990). This behaviour may be of territorial significance.

Flat areas of open leaf-litter on the forest floor are selected when feeding, and densely vegetated areas such as creeks, swamps and steep slopes are avoided (Allport et al. 1989, Allport in prep., M. E. Gartshore pers. comm. 1990): this selection may reflect good feeding, visibility and ease of escape on the ground and in the air.

Food consists mainly of invertebrates gleaned from the leaf-litter, particularly worker termites (Bechinger 1964, M. E. Gartshore pers. comm. 1990). Within a feeding group birds are attracted to an area where others are pecking, suggesting that the group is foraging for a patchy resource (M. E. Gartshore pers. comm. 1990). It may be that this is more difficult during the wet season when the litter creates less noise.

Threats Habitat destruction and hunting are the main threats to this species. The compact flocks make an easy target as up to ten birds may be hit with one shot (M. E. Gartshore pers. comm. 1990). They are attracted by imitations of their squeaking call (pers. obs.), or noisy stirring of leaf-litter (Dutson and Branscombe in prep.), which presumably suggests feeding birds. The relationship between meat-yield and cost of cartridges makes this species uneconomical to hunt in Sierra Leone but unfortunately this is not the case elsewhere in its range. It is extremely rare in the secondary areas of Gola, which may be as a result of trapping by logging company personnel, a potentially widespread problem. One bird was found in a leg-hold snare in Ghana (Dutson and Branscombe in prep.) and local people use similar traps in Sierra Leone although catch rates are extremely low even in pristine forest (Allport et al. 1989).

Recent surveys have found the species to be hanging on in areas where it was previously thought to be extinct. However this is not a particularly difficult species to locate, and may well be long-lived; thus the few records from areas such as Nini-Suhien National Park, although a cause for some optimism, may not be indicative of long-term viable populations (Dutson and Branscombe in prep.). Healthy populations are known to exist only in Taï and Gola; the continued survival of this species is heavily dependent upon the protection of these areas from logging encroachment and hunting. Important sites for this species may well be located in the substantial forests of south-eastern Liberia but hunt- 
ing pressure is intense in the region and likely to worsen in the short term (Taylor 1988, S. Anstey pers. comm. 1990).

Rufous Fishing Owl

RARE

Distribution Occurs throughout the main Upper Guinea forest. An extremely rarely recorded and little known bird, but recent records from Ghana to Sierra Leone confirm its continued existence. Ghana: two recent records from Western Province (Taylor ms). Ivory Coast: single birds seen at Lamto and Taï. An immature bird discovered in Abidjan Zoo is of unknown provenance (Demey and Fishpool in prep., M. E. Gartshore pers. comm. 1990). Liberia: no recent data but two live specimen records have recently come to light. A male taken near Salayah, Lofa County, on 13 December 1972 and a female from 10 miles south-east of Monrovia on 23 March 1973. Both are thought to have been juveniles when brought into captivity (P. J. S. Olney pers. comm. 1990). Sierra Leone: a captive juvenile bird found on the periphery of Gola had been taken from a nearby riparian forest remnant (Allport et al. 1989).

Population Population sizes are not known but the species is either very rare or extremely elusive.

Ecology Most records relate to birds near water in forest. There is only one fully confirmed record from mangrove (G. D. Field pers. comm. 1989) since it is unclear whether the records from Azagny, Ivory Coast (Thiollay 1985a), refer to calls or sightings: the former may be inaccurate (see later). However a recently established record from near Monrovia is very likely to have been in this habitat.

Normally seen at dusk or dawn so is either nocturnal or crepuscular. One bird was observed following a narrow forest stream in broad daylight. It made short flights along the $2-3 \mathrm{~m}$ wide watercourse, perching on branches $c .2 \mathrm{~m}$ above the ground (P. D. Taylor pers. comm. to A. Gretton 1990). The call of this species remains unknown, the recording on Chappuis's (1978) discs having recently been identified as White-crested Tiger Heron (Fishpool et al. 1989). Obtaining a recording of the correct call is a high priority since it might enable thorough surveys of this species to be undertaken.

Threats Habitat destruction is probably the main threat, but river pollution is an additional factor since the clarity of forest streams could be important for effective foraging. Deforestation often causes higher sediment loading in rivers, increasing their turbidity; thus such activities upstream of a site could affect the owl. There have been proposals for dams in the region which would also have detrimental effects. If this species is reliant on larger fish for food, then overfishing of the clear rivers in forest could have a significant impact. Several records refer to trapped birds which may conceivably pose an additional threat.

It is possible that this species still survives in mangrove areas such as Azagny in Ivory Coast (Thiollay 1985a). Such habitat may yet prove to hold this species further west than has hitherto been noted. 
Distribution The very few records of this species show that it probably occurs throughout the Upper Guinea forest and Cameroon (one record only). The records from Liberia and Sierra Leone represent a significant westward range extension from Nimba. Ivory Coast: several sightings of thin-billed honeyguides in Tai may have been of this species (Gartshore 1989). Liberia: collected in the Wonegizi Mountains in Lofa County, 1990 (R. W. Dickerman in litt. 1991). Sierra Leone: one sight-record in Gola (Allport et al. 1989).

Population No estimate of numbers has been possible but even allowing for the difficulty of recording a canopy-dweller it must be a very rare bird.

Ecology Found in primary forest although one possible sight record (pre-1985) comes from a secondary area (Macdonald 1980). It feeds in a manner reminiscent of a sylviid warbler or a sunbird in the mid- or upper canopy (P. V. Hayman pers. comm. 1989; also Short and Horne 1985). This species is presumably a brood parasite and the host - on which it presumably depends - is unknown.

Threats The apparently low population density makes it potentially vulnerable to fragmentation of its forest habitat. This species would warrant inclusion in the "vulnerable" category of threat if it were not for the record from Cameroon, which suggests an insufficiently known Guineo-Congolian distribution.

Distribution Recent records have shown this species to be widespread within the Upper Guinea forest from Sierra Leone to Ghana. Ghana: found in NiniSuhien National Park and Boin-Tano Forest Reserve (Dutson and Branscombe in prep.). Ivory Coast: recent records from the managed forest at Yapo (Demey and Fishpool in prep.) and in Taii (Gartshore 1989). Liberia: recorded in the forests of Nimba, Grand Gedeh County, Sapo, Lofa Mano and Wonegizi Mountains (Carter 1987, Collar and Stuart 1988, Dickerman et al. 1988, Gartshore 1989, R. W. Dickerman in litt. 1991). Sierra Leone: only recorded in Gola but present in both forest reserves there (Allport et al. 1989). Guinea: recent records from Diecké and probably Ziama (R. Wilson pers. comm. 1990).

Population This species is usually encountered in mid-storey bird parties. In Gola $39 \%$ of parties in primary forest held this species, but this dropped to $19 \%$ in logged areas, and the parties themselves were rarer in this habitat. The density estimate in primary areas was $0.98-2.92 \mathrm{birds} / \mathrm{km}^{2}$ and $0.57-1.14$ birds/ $\mathrm{km}^{2}$ in logged forest (Allport et al. 1989). It is frequent in the managed forest of Yapo, but much rarer in Tai where it is usually seen in natural secondary growth such as riverine areas (Demey and Fishpool in prep., M. E. Gartshore pers. comm. 1990).

Ecology Restricted to forest, where singles, pairs and occasional threesomes are found almost solely in mixed species bird parties in the mid-storey of the forest. It 
is one of the most regular species in such parties along with birds such as Icterine Greenbul Phyllastrephus icterinus; its occurrence is strongly associated with Yellow-bearded Greenbul Criniger barbatus and White-bearded Greenbul C. calurus within these groups (Allport et al. 1989, in prep.).

Threats Threatened by total forest clearance but logging reduces the density and thus the total population at any one site, thereby making particular populations more vulnerable.

This species was described after the publication of the Red Data Book and was first included in the threatened list by Collar and Andrew (1988).

Distribution The type-locality is in semi-deciduous forest $20 \mathrm{~km}$ north-west of Zwedru, Grand Gedeh County in south-east Liberia (Figure 2; Gatter 1985). This distinctive species might be expected to occur in similar habitat elsewhere but, despite considerable recent survey efforts in adjacent forest in Ivory Coast, there have been no other records.

Population There is no estimate of the population but it is likely to be small.

Ecology The species is found in transitional zone between evergreen and semideciduous tropical rainforest during the dry season (December-March) where it occurs in bird parties with other typical party species such as Icterine Greenbul, White-bearded Greenbul, Fraser's Scarlet-tufted Sunbird Anthreptes fraseri and on one occasion Gola Malimbe (Gatter 1985). Whether this species is a local migrant or becomes less obtrusive in the wet season is not clear.

Threats The lack of records from other sites suggests that this easily identifiable species is of very restricted distribution. Clearance of forest within this area is not controlled and in the current political climate the species's future is very uncertain.

\section{Nimba Flycatciner}

VULNERABLE

Distribution This species has only been recorded in the western part of the Upper Guinea forest, the most southern and eastern records being from the south of Taï (Figure 2). Ivory Coast: only records from Taï (Balchin 1988, Gartshore 1989, Demey and Fishpool in prep., M. E. Gartshore pers. comm. 1990). Liberia: despite searches there have been no recent records from Nimba. Recently located at a new site at Glaro in the eastern part of Grebo. Appears to be absent from the southerly and coastal forests (Gatter 1988). Sierra Leone: located in Gola, but only in one of the reserves (Allport et al. 1989). Guinea: one record from Ziama (R. Wilson pers. comm. 1990).

Forbes-Watson (1975) mentions an observation of this species by $C$. Erard in Gabon, and on the basis of this Louette (1981) suggested that it could occur in Cameroon. Erard himself does not mention the observation in two subsequent 
works (Brosset and Erard 1986, Erard 1990), so it is assumed here that the record was not confirmed and that the species is indeed an Upper Guinea forest endemic.

Population Population density was estimated at $0.5^{-2}$ birds $/ \mathrm{km}^{2}$ yielding a total population of 690 in the three Gola Forest Reserves, but it may be extinct from two of these areas, in which case the total may be as low as 475 birds (Allport et al. 1989). Four singing birds were recorded along $12.5 \mathrm{~km}$ of trail in Taï, suggesting a higher density of approximately $4 \mathrm{birds} / \mathrm{km}^{2}$ (assuming detectability distance is $150 \mathrm{~m}$ and one bird per pair sings) (M. E. Gartshore pers. comm. 1990). Although a difficult bird to see in the canopy it does seem to be a genuinely rare bird. However, a recent recording of its song (M. E. Gartshore pers. comm. 1990) should ease survey work in the future. No quantitative surveys have been undertaken in the main wet season when this species would be expected to be most vocal.

Ecology A forest canopy-dweller only recorded outside of primary habitat at Taï (Demey and Fishpool in prep., M. E. Gartshore pers. comm. 1990). It occurs in monospecific groups of up to five birds, high in large emergent trees where it hawks insects, and hover-gleans prey from the bark. It is occasionally associated with mixed bird parties. All records come from lowland forest ( $<1,000 \mathrm{~m}$ a.s.l.). Breeding takes place in the wet season: adults seen feeding fledged young in June in Taï (A. Jaramillo pers. comm. to M. E. Gartshore 1990) and breeding condition adults collected in July-August on Nimba (Forbes-Watson 1970).

Threats This species's preference for large emergents may have major consequences for its survival since such trees are often felled or damaged in selective logging operations.

The range of this species lies almost wholly within the Upper Guinean wet/dry mosaic forest (habitat-type 3 in White 1983; Figure 2). The largest remaining area of this forest-type lies in central and northern Liberia (58\%; see Appendix 1). The Gola-Kpelle-Belle National Park complex is likely to support a very significant population. However, Taii holds the population with the best future prospects. A substantial but vulnerable area of this forest type remains in eastern Guinea, where no recent forest conservation measures have been taken and habitat loss is progressing rapidly ( $R$. Wilson pers. comm. 1990).

Western Wattled Cuckoo-shrike

VULNERABLE

Distribution Occurs throughout the main Upper Guinea forest. Ghana: one recent record from Cape Three Points Forest Reserve is the first in the country since 1935 (Taylor ms). Ivory Coast: regular records from Taï and one recent record from Nimba (Gartshore 1989, Demey and Fishpool in prep.). Liberia: one seen in Lofa County, March 1989 (M. E. J. Gore pers. comm. 1991). Sierra Leone: three recent records from Gola (Allport et al. 1989). Guinea: one record from Ziama (D. Halleux pers. comm. to R. Wilson 1990).

Population In Taï it has been seen fairly frequently from canopy platforms 
(M. E. Gartshore pers. comm. 1990). In five months of recent surveys in Gola this species was only recorded three times (Allport et al. 1989), whereas it was recorded on 20 occasions in 62 days in the early 1970 in logged areas of the forest (G. D. Field pers. comm. 1989).

Ecology A bird of the upper storey and forest canopy, penetrating secondary areas and occasionally cocoa plantation (Gartshore 1989, Demey and Fishpool in prep.). Usually seen singly or in pairs, occasionally in bird parties (G. D. Field pers. comm. 1989). A nest found $c .30 \mathrm{~m}$ up in a large Xylopia sp. in logged forest in Gola contained downy young in early January. Adults brought damselflies, orthoptera and larvae, and fed them directly to the chicks (Allport et al. 1989). Well-grown juveniles were seen in Gola in May (Collar and Stuart 1985). A female was seen building a nest high-up on the end of a limb of a Ceiba pentandra in early May in Taï (M. E. Gartshore pers. comm. 1990).

Threats This species has been considered to be dependent on primary forest (Collar and Stuart 1985), but there are a number of records from secondary forest habitats including breeding. However the undoubted decline of this species in Gola may well be attributable to the logging of primary areas and the relogging of secondary forest; therefore this species must be seen as threatened by such activities.

Distribution Occurs throughout the Upper Guinea forest. Ivory Coast: breeding now confirmed at Lamto after ten years of sporadic records (Demey and Fishpool in prep.). A colony located on Mt Niénokoué in the south-east of Taï is the first to be found in the park (Gartshore 1989). Recent information suggests that this species still persists on Nimba (M. de Gaulle pers. comm. to M. E. Gartshore 1989). Liberia: described by local people in Grebo and Krahn-Bassa (S. Anstey pers. comm. 1990) and "large numbers" claimed in Belle National Forest $(\mathrm{H}$. Gilmore pers. comm. to S. Anstey 1990); one was collected in the Wonegizi Mountains, 1990 (R. W. Dickerman in litt. 1991). Sierra Leone: small colonies still exist on the Freetown Peninsula (Thompson 1990) and new colonies have been located in Gola (Allport et al. 1989, H. S. Thompson pers. comm. 1990). Guinea: colonies located in Ziama and local people described this species in Diecké ( $R$. Wilson pers. comm. 1990).

Cheke (1986) pointed out that the records attributed to a locality in Togo by Collar and Stuart (1985) were more likely to have referred to a site in Ghana. He did, however, suggest that this species may well be found in the Atacora Hills in Togo.

Population This species is a colonial breeder, building swallow-like mud cups on bare rock-faces with up to 50 nests at a single location. A survey of Gola found 30 colonies containing a total of 197 nests. Twenty-one of these colonies were active, with 116 nests showing signs of recent use (Allport et al. 1989). Further work has located 13 more colonies (H. S. Thompson pers. comm. 1990). This site is clearly a major stronghold for the species. An intensive survey of the 
Freetown Peninsula found eight colonies containing 18 nests (Thompson 1990). This population must be small and possibly on the brink of viability. Taï probably holds only a small breeding population due to a lack of suitable breeding habitat (M. E. Gartshore pers. comm. 1990). At Lamto one colony with around 20 birds in attendance was recently located (Demey and Fishpool in prep.).

Ecology This forest bird has been found to persist in logged areas (Grimes and Darku 1968), but in Gola all colonies outside of the forest cover have been abandoned (Allport et al. 1989). It feeds on the ground in the manner of a thrush Turdus, and has been recorded in the bird parties which attend ant columns (Field 1974, Ausden and Wood 1990). Nesting colonies are normally located on large, dry, rocky overhangs (Allport et al. 1989) but where these are absent single nests have been found on banks of watercourses (G. D. Field pers. comm. 1989, Thompson 1990) and once reported on fallen trees (H. Gilmore pers. comm. to S. Anstey 1990). There is evidence of synchrony in the timing of breeding within colonies in Ghana (Grimes and Darku 1968) but in the western part of the region laying commences both before and after the wet season (Allport et al. 1989). Birds may disperse widely outside of the breeding season, indicated by occasional records of feeding birds in very degraded habitat (Allport et al. 1989).

Threats Clearance of forest is a threat but this species seems tolerant of quite considerable habitat damage particularly when choosing feeding areas. However, these birds are extremely vulnerable at breeding sites, the availability of which could determine the population level in an area. In Sierra Leone collecting for zoos is still prevalent but chicks are only normally taken for food by migrant Liberian hunters (Allport et al. 1989). In Guinea local people described catching adults at colonies for food, the easy access and small number of breeding birds at a site making this a very serious threat (D. Halleux pers. comm. to R. Wilson 1990).

Note In eastern Sierra Leone the Mendé people worship the gods of the rocks on which picathartes nest. The birds are seen as sacred embodiments of the gods and as such are held in reverence (Allport et al. 1989).

Gola Malimbe

VULNERABLE

Distribution This forest weaver is very locally distributed within the western part of the Upper Guinea forest (Figure 2). Ivory Coast: possibly seen recently in Taï (M. E. Gartshore pers. comm. 1990). Liberia: recent records are from unprotected forests in the north of Grand Gedeh County (Gutter 1985), Lofa Mano (Collar and Stuart 1988) and Sapo (S. Anstey pers. comm. 1990, M. E. J. Gore pers. comm. 1990).

Population Although described as frequent in one area of Sapo (S. Anstey pers. comm. 1990), on a wider scale it is clearly rare or restricted to a very specific habitat-type: an eight-week survey of Sapo failed to locate the species (Carter 1987), but two pairs were found there within $0.5 \mathrm{~km}$ of each other, November 1988 (M. E. J. Gore pers. comm. 1990). The area where this bird occurred in Gola 
(Field 1979) was thoroughly searched in 1989 without success (Allport et al. 1990), and major survey efforts in Taii have been similarly disappointing (Gartshore i989).

Ecology Found in the forest mosaic habitat (White 1983) similar to that of Nimba Flycatcher and Spot-winged Greenbul. A particular group was regularly seen over a six-year period in Gola in an area of logged forest less than $2 \mathrm{~km}$ across (Field 1979) but could not be relocated 10 years later (Allport et al. 1989). It is possible that they were not immediately affected by logging but were sensitive to long-term effects. Such isolated populations must be extremely sensitive to fragmentation both between and within forest blocks. The two pairs in Sapo, November, were feeding high up but below the canopy of riparian forest; one of these pairs was seen carrying nesting material (M. E. J. Gore pers. comm. 1990).

Threats This conspicuous species has not been seen recently in either Gola or Tai despite considerable survey efforts, giving cause for concern. The climate in Tai has recently become much drier and it may be significant that this bird appears most frequently observed in Sapo, one of the wettest ares in the Upper Guinea forest (M. E. Gartshore pers. comm. 1990). Sapo and the other forests in south-east Liberia (e.g. Krahn-Bassa) may therefore be of prime importance for this species.

\section{Near-threatened species}

Rufous-winged Illadopsis Widespread and common in primary and secondary areas throughout the Upper Guinea forest, easiy detectable by its call.

Surveys of calling birds in Ghana found 12 calling birds $/ \mathrm{km}^{2}$ in forest logged 17 years ago, 9 birds $/ \mathrm{km}^{2}$ in newly logged forest but there were only 3 birds $/ \mathrm{km}^{2}$ in primary habitat (Dutson and Branscombe in prep.). Similar surveys in Gola located $14-18$ birds $/ \mathrm{km}^{2}$ in primary forest and $2-6$ birds $/ \mathrm{km}^{2}$ in logged areas (Allport et al. 1989).

Very degraded habitats are occasionally penetrated by this species but only on the periphery of forest, and therefore despite its frequency this species would be threatened by total forest destruction.

Copper-tailed Glossy Starling Of variable frequency but often common in primary forest, but usually even more numerous in secondary areas (Allport et al. 1989, Gartshore 1989). Freely ranges out of forest into surrounding farmbush, often nesting in dead trees left upstanding following burning. It is absent away from forest and in areas of older farmbush where dead trees have fallen; thus despite an immediate tolerance of forest clearance, this species is ultimately threatened by this eventuality.

Brown-cheeked Hornbill This species was considered for inclusion in the Red Data Book (Collar and Stuart 1985), but not treated as either threatened or near-threatened.

Formerly noted as common in certain forests in Ivory Coast (Thiollay 1985a), but recent surveys have found it to be uncommon at most sites; it is the sixth 
most frequent hornbill in Taii (Gartshore 1989). It has been recorded in cocoa plantations and farmbush but only where adjacent to forest (Allport et al. 1989).

This species along with other large hornbills is occasionally shot for food and could be sensitive to increasing human pressures (Thiollay $1985 \mathrm{~b}$ ). It seems very likely that total forest clearance is a threat and so this species should be added to the near-threatened list.

Baumann's Greenbul This is extremely rare in the Upper Guinea region with only one recent record (Allport et al. 1989), but is noted as not uncommon in secondary forest and forest edge in southern Nigeria (Elgood 1982), so is probably secure there.

\section{Other important species}

The regional extinction of a further set of species would follow if all of the Upper Guinea forest was to be completely destroyed. An additional 28 candidate species for the Red Data Book are regionally threatened by this eventuality (see Appendix 2) and of these there is a further subset of seven species, none of which is endemic to the Upper Guinea forest, which were identified by Thiollay (1985b) as being of concern because of their restricted distribution or rarity (Appendix 2).

There are also five endemic species which occur outside of high forest which, although not directly relevant to this discussion, warrant careful monitoring (Appendix 2).

\section{Discussion}

White-breasted Guineafowl remains the most endangered bird in the Upper Guinea. It is known to be common at only two sites and its assured existence hinges, in the short term, on the protection of these, but the sensitivity of this bird to hunting hinders this task. The three "western" endemics - Spot-winged Greenbul, Nimba Flycatcher and Gola Malimbe - are all limited to the wet/dry mosaic forests of which Liberia contains $58 \%$ and Guinea $23 \%$ of the remaining habitat. It is clear that the future of the greenbul and malimbe lies in these two countries and with the current political climates it is difficult to be sure of their prospects. The flycatcher occurs in substantial numbers in Tai and should be at least adequately protected there.

Three of the threatened species are canopy dwellers which are notoriously difficult to locate and study. Intensive canopy work must be a major element of any future research project in the region if we are to understand the ecologies of these species sufficiently to identify their requirements. The use of canopy platforms has already begun in Ghana and Ivory Coast (Cole 1990, Dutson and Branscombe in prep., M. E. Gartshore pers. comm. 1990).

As pressure increases on the tropical West African nations to produce more wood for the international timber market, the range of forestry practices must inevitably expand to encompass plantation production. The implications for bird communities are unknown. Surveys in plantation areas are a priority for future 


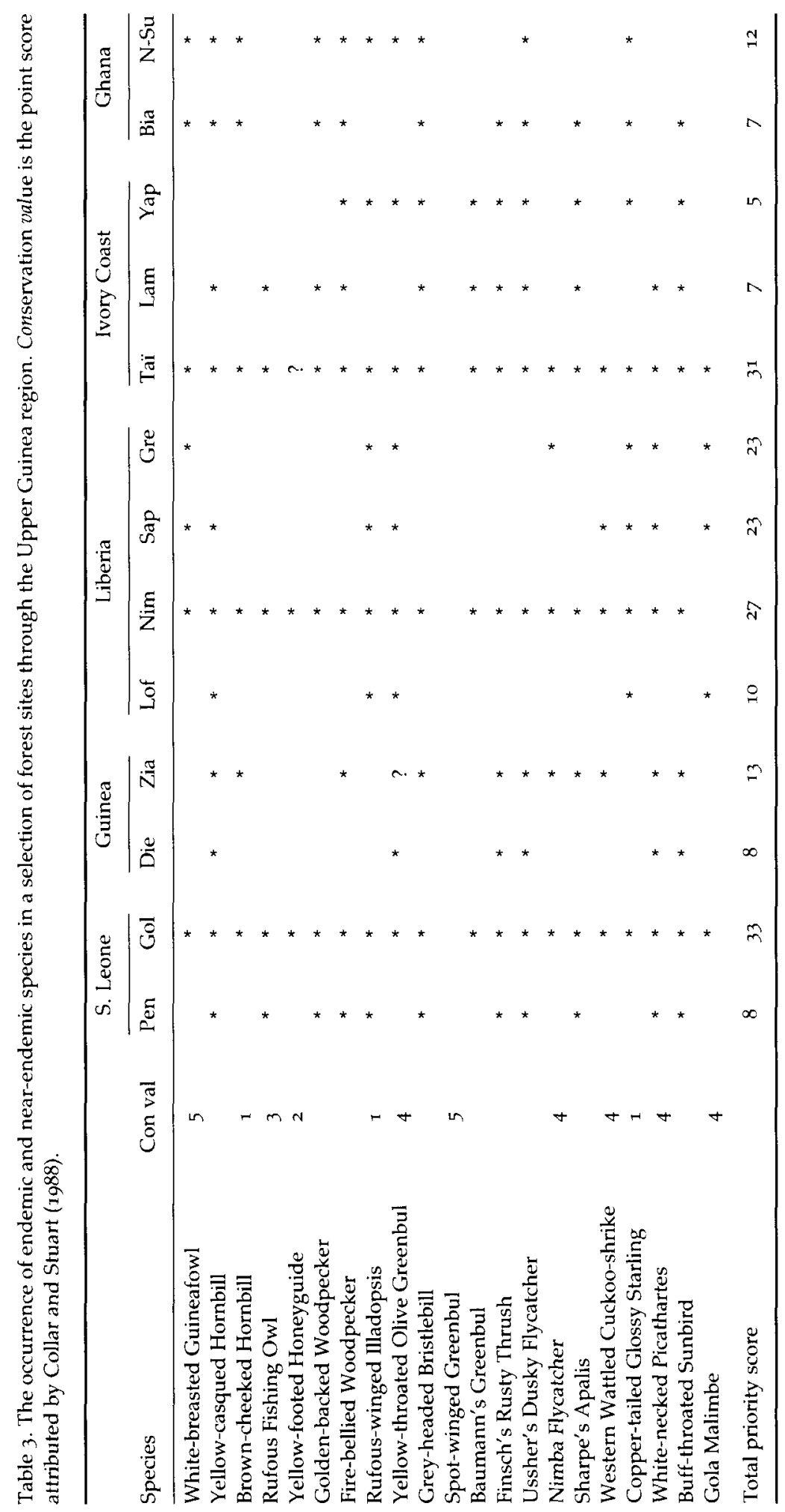


work, but care must be taken to isolate the effects of proximity to existing forest cover.

Three bird species new to science - Yellow-footed Honeyguide, Nimba Flycatcher and Gola Malimbe - have been described from this region in the last 25 years, and two more are strongly suspected: a forest oxpecker seen in Taï (Thiollay 1985a), and a distinctive sunbird seen in Gola (Allport 1989). More species of forest bird may remain undescribed and these could already be on the edge of extinction. Very little intensive work has been undertaken on the nocturnal species of primary forest and this may well prove to be rewarding.

The Upper Guinea forest has been severely fragmented and throughout much of the area conservation efforts now follow a site-based plan by necessity. Individual sites have been placed in regional context according to the important bird species recorded therein (Collar and Stuart 1988), Taï and Gola emerging as very high priorities (Table 3). It must be borne in mind, however, that this assessment reflects survey effort to a great extent. There are some species of limited range within the forest block whose occurrences are probably restricted to a few sites but, should they be subjected to sufficient scrutiny, the majority of substantial areas of forest will very probably reveal most of the important species. Thus the overall value of particular sites should be assessed using data on the extent and condition of the habitat.

The most extensive remaining forests are those of south-eastern Liberia and these are now of the highest priority for thorough survey work. Key sites are the national forests of Krahn-Bassa and Grebo as well as Sapo National Park. The unprotected Barrobo forest in central Mary Land County is probably the most southerly remaining forest in the western Upper Guinea block and this may prove a productive area for future work (S. Anstey pers. comm. 1990). Further north and west, the Liberian sector of Gola and the contiguous Kpelle and Belle national forests are likely to support important bird populations, particularly of Nimba Flycatcher. In Guinea the recently surveyed forests of Diecké and Ziama should be targets for further work. In addition, forest patches near Conakry may also hold key bird species (R. Wilson pers. comm. 1990). In the extreme east, the forest patches in eastern Ghana/western Togo (Figure 3) may support the picathartes and would be worthy of investigation.

The set of sites currently illuminated by this discussion must not be seen as exclusive. Other sites such as Loma in northern Sierra Leone and Mount Peko in Ivory Coast may well prove to be as important as other areas already well known as the result of intensive survey efforts. 


\section{Appendix 1}

Extent of forest cover $\left(\mathrm{km}^{2}\right)$ in the five main countries of the Upper Guinea region (data from Gordon et al. 1979, Mackinnon and Mackinnon 1986, Poore et al. 1989, S. Anstey pers. comm. 1990). Forest-types from White (1983): Type 1a, wet guineo-congolian forest; Type 2, drier guineo-congolian forest; Type 3, mosaic of 1a and 2; Type 8, swamp forest; $O$, original extent; $R$, remaining extent. These data will be updated in WCMC/IUCN (in prep.).

\begin{tabular}{|c|c|c|c|c|c|c|c|}
\hline \multirow[t]{2}{*}{ Country } & & \multicolumn{4}{|c|}{ Forest-types } & \multirow[t]{2}{*}{ Total forest area } & \multirow{2}{*}{$\begin{array}{l}\text { \% of total } \\
\text { Upp. Guinea }\end{array}$} \\
\hline & & $1 a$ & 2 & 3 & 8 & & \\
\hline \multirow[t]{2}{*}{ Guinea } & $\mathrm{R}$ & & & 7,721 & & 7,721 & 9.9 \\
\hline & $\%$ & & & $\begin{array}{r}1401 \\
19,300\end{array}$ & & $\begin{array}{c}\{40\} \\
19,300\end{array}$ & 5.8 \\
\hline \multirow[t]{3}{*}{ Sierra Leone } & $\mathrm{R}$ & & & 2,870 & 780 & 3,650 & 4.7 \\
\hline & $\%$ & & & (52) & $(26)$ & (43) & \\
\hline & $\mathrm{O}$ & & & 5,500 & 3,000 & 8,500 & 2.5 \\
\hline \multirow[t]{3}{*}{ Liberia } & $\mathrm{R}$ & 19,600 & & 19,500 & $?$ & 39,100 & 49.8 \\
\hline & $\%$ & $(63)$ & & (31) & (?) & (42) & \\
\hline & $\mathrm{O}$ & 31,300 & & 61,800 & 200 & 93,300 & 27.9 \\
\hline \multirow[t]{3}{*}{ Ivory Coast } & $\mathrm{R}$ & 6,280 & 8,160 & 3,430 & 1,680 & 20,000 & 25.6 \\
\hline & $\%$ & (1.4) & (14) & (14) & $(56)$ & (15) & \\
\hline & $\mathrm{O}$ & 44,900 & 61,500 & 24,500 & 3,000 & 133,900 & 40.1 \\
\hline \multirow[t]{3}{*}{ Ghana } & $\mathrm{R}$ & 1,830 & 6,030 & & & 7,860 & 10.0 \\
\hline & $\%$ & (10) & (10) & & & (10) & \\
\hline & $\mathrm{O}$ & 18,300 & 60,300 & & & 78,600 & 23.6 \\
\hline Remaining area & & $27,7^{10}$ & 14,640 & 33,521 & 2,460 & 78,231 & \\
\hline Original area & & 94,500 & 121,800 & 111,100 & 6,200 & 333,600 & \\
\hline$\%$ remaining & & 29 & 12 & 30 & 40 & 23 & \\
\hline
\end{tabular}

\section{Appendix 2}

Species included or considered for inclusion in the threatened categories of the Red Data Book (Collar and Stuart 1985) which occur within, but are not necessarily restricted to, the Upper Guinea forest block. Birds which would be threatened by total forest clearance are marked with an asterisk. Underlined are those species identified by Thiollay (1985b) as being of concern, but are not currently included in any of the threatened or near-threatened categories. +, species not found in primary forest but are of restricted distribution. Scientific names of species not listed below but mentioned in the main text by English name only are: Fire-bellied Woodpecker Dendropicos pyrrhogaster, Grey-headed Bristlebill Bleda canicapilla, Baumann's Greenbul Phyllastrephus baumanni, Finsch's Rusty Thrush Stizorhina finschi and Buff-throated Sunbird Nectarinia adelberti.

White-crested Tiger Heron

White-backed Night Heron

Olive Ibis

Spot-breasted Ibis

Congo Serpent Eagle
Tigriornis leucolopha

Nycticorax leuconotus

Bostrychia olivacea

B. rara

Dryoscopus spectabilis 
Appendix 2 (cont.)

Long-tailed Hawk

African Hawk Eagle

Cassin's Hawk Eagle

Ahanta Francolin

White-breasted Guineafowl

African Skimmer

Black-collared Lovebird

Thick-billed Cuckoo

Red-chested Owlet

Sandy Scops Owl

Maned Owl

Shelley's Eagle Owl

Akun Eagle Owl

Rufous Fishing Owl

Brown-cheeked Hornbill

Yellow-casqued Hornbill

Brown Nightjar

Black Spinetail

Bates's Swift

Lyre-tailed Honeyguide

Yellow-footed Honeyguide

Golden-backed Woodpecker

Yellow-throated Olive Greenbul

Spot-winged Greenbul

Western Wattled Cuckoo-shrike

Turati's Boubou

Lagden's Bush-shrike

Copper-tailed Glossy Starling

Northern Bearded Scrub-robin

Grey Ground-thrush

Rufous-winged Illadopsis

Puvel's Illadopsis

Sharpe's Apalis

Kemp's Longbill

White-eyed Prinia

Black-headed Stream Warbler

Olivaceous Flycatcher

Tessmann's Flycatcher

Nimba Flycatcher

Ussher's Dusky Flycatcher

Violet-backed Hyliota

White-browed Batis

Red-cheeked Wattle-eye

White-spotted Wattle-eye

White-necked Picathartes

Gola Malimbe

Crimson Seedcracker

Urotriorchis macrourus

Hieratus spilogaster

Spizaetus africanus

Francolinus ahantensis

Agelastes meleagrides

Rynchops flavirostris

Agapornis swinderniana

Pachycoccyx audeberti

Glaucidium tephronotum

Otus icterorhynchus

Jubula lettii

Bubo shelleyi

$B$. leucostictus

Scotopelia ussheri

Ceratogymna subcylindricus

C. elato

Caprimulgus binotatus

Chaetura melanopygia

Apus batesi

Melichneutes robusta

Melignomon eisentrauti

Campethera maculosa

Criniger olivaceus

Phyllastrephus leucolepis

Campephaga lobata

Laniarius turatii

Malaconotus lagdeni

Lamprotornis cupreocauda

Cercotrichus leucostictus

Zoothera princei

Illadopsis rufescens

I. puveli

Apalis sharpei

Macrosphenus kempii

Prinia leontica

Bathmocercus cerviniventris

Muscicapa olivascens

M. tessmanni

Melaenornis annamarulae

Artomyas ussheri

Hyliota violacea

Bat is occultus

Platysteira blisseti

P. tonsa

Picathartes gymnocephalus

Malimbus ballmanni

Haematina spermophaga

\section{References}

Allport, G. A. (1989) West of the Dahomey Gap. World Birdwatch 11(4): 9.

Allport, G. A. (in prep.) Feeding site selection by White-breasted Guineafowl.

Allport, G. A., Ausden, M., Hayman, P. V., Robertson, P. and Wood, P. (1989) The conservation of the birds of the Gola forest, Sierra Leone. Cambridge, U.K.: International Council for Bird Preservation (Study Report 38). 
Allport, G. A., Ausden, M. J. and Wood, P. (in prep.) The species composition of bird parties in primary and secondary forest in two areas of Sierra Leone.

Ausden, M. and Wood, P. (1990) The wildlife of the Western Area Forest Reserve, Sierra Leone. Unpublished.

Balchin, C. S. (1988) Recent observations of birds from the Ivory Coast. Malimbus 1o(2): 201-206.

Bechinger, F. (1964) Beobachtungen am Weissbrust-Waldhuhn (Agelastes meleagrides) im Frieleben und in der Gefangenschaft. Gefied. Welt 88: 61-62.

Brosset, A. and Erard, C. (1986) Les oiseaux des régions forestières du nord-est du Gabon, I. Paris: Société Nationale de Protection de la Nature.

Carter, M. F. (1987) Initial avifaunal survey of Sapo National Park, Liberia. Unpublished report to World Wildlife Fund and the Forestry Development Authority, Liberia.

Chappuis, C. (1978) Les oiseaux de l'Ouest Africaine. Sound suppl. to Alauda. Disks 1-13.

Cheke, R. A. (1986) The supposed occurrence of the White-necked Picathartes Picathartes gymnocephalus in Togo. Bull. Brit. Orn. Club 106: 152.

Cole, M. (1990) Canopy access in Taï National Park, Ivory coast. Unpublished report to ICBP.

Collar, N. J. and Andrew, P. (1988) Birds to watch: the ICBP world checklist of threatened birds. Cambridge, U.K.: International Council for Bird Preservation (Techn. Publ. 8).

Collar, N. J. and Stuart, S. M. (1985) Threatened birds of Africa and related islands. Cambridge, U.K.: International Council for Bird Preservation.

Collar, N. J. and Stuart, S. M. (1988) Key forests for threatened birds in Africa. Cambridge, U.K.: International Council for Bird Preservation (Monogr. 3).

Colston, P. and Curry-Lindah1, K. (1986) The birds of Mount Nimba, Liberia. London: British Museum (Natural History).

Davies, A. G. (1987) The Gola forest reserves, Sierra Leone: wildlife conservation and forest management. Gland, Switzerland and Cambridge, U.K.: International Union for Conservation of Nature and Natural Resources.

Demey, R. and Fishpool, L. D. C. (in prep.) Additions and annotations to the avifauna of Côte d'Ivoire.

Dickerman, R., Carter, M. F. and Cane, W. P. (1988) Birds collected in south-east Liberia. Unpublished.

Dutson, G. and Branscombe, J. (in prep.) Rainforest birds in south-west Ghana. Cambridge, U.K.: International Council for Bird Preservation (Study Report 46).

Erard, C. (1990) Écologie et comportement des gobe-mouches (Aves: Muscicapinae, Platysteirinae, Monarchinae) du nord-est du Gabon, 2: organisation sociale et écologie de la reproduction des Muscicapinae. Mém. Mus. Natn. Hist. Nat., Zool. 146.

Field, G. D. (1974) The birds of the Freetown Peninsula. Mount Aureol, Freetown, Sierra Leone: Fourah Bay College Bookshop Ltd.

Field, G. D. (1979) A new species of Malimbus sighted in Sierra Leone and a review of the genus. Malimbus 1: 2-13.

Fishpool, L. D. C., van Rompaey, R. and Demey, R. (1989) The call of White-crested Tiger Heron attributed to Rufous Fishing Owl. Malimbus 11: 96-97.

Forbes-Watson, A. D. (1970) A new species of Melaenornis (Muscicapinae) from Liberia. Bull. Brit. Orn. Club go: 145-148.

Forbes-Watson, A. D. (1975) Letter: Mackworth-Praed and Grant. Bull. Nigerian Orn. Soc. 11(39): 44 .

Fry, C. H., Keith, S. and Urban, E. K. (1988) The birds of Africa, 3. London: Academic Press.

Gartshore, M. E. (1989) An avifaunal survey of Taï National Park, Ivory Coast. Cambridge, U.K.: International Council for Bird Preservation (Study Report 39).

Gatter, W. (1985) Ein neuer Bülbül aus Westafrika (Aves, Pycnonotidae). J. Orn. 126: 155-161. 
Gatter, W. (1988) The birds of Liberia (West Africa): a preliminary list with status and open questions. Verh. Orn. Ges. Bayern. 24: 689-723.

Gatter, W., Peal, A., Steiner, C. and Weick, F. (1988) The unknown immature plumages of the rare White-breasted Guineafowl. Okol. Vögel 10: 105-111.

Gilpin, M. E. and Soulé, M. E. (1986) Minimum viable populations: processes of species extinction. Pp. 19-34 in M. E. Soulé, ed. Conservation biology: the science of scarcity and diversity. Sunderland, Mass.: Sinauer Associates.

Gordon, O. L. A., Kater, G. and Schwaar, D. G. (1979) Vegetation and land use in Sierra Leone. UNDP/FAO (Techn. Rep. No.2 AG:DP/SIL/73/002).

Grimes, L. G. (1987) The birds of Ghana. London: British Ornithologists' Union (Check-list no.9).

Grimes, L. G. and Darku, K. (1968) Some recent breeding records of Picathartes gymnocephalus in Ghana and notes on its distribution in West Africa. Ibis 110: 93-99.

Hosking, E. (1982) Eric Hosking's owls. London: Mermaid Books.

Kingdon, J. (1990) Island Africa. London: Collins.

Louette, M. (1981) The birds of Cameroon: an annotated checklist. Brussels: Verhandeling Wetenschappen, Jaargang 43, no. 163.

Macdonald, M. A. (1980) Further notes on uncommon forest birds in Ghana. Bull. Brit. Orn. Club 100: 170-172.

Mackinnon, J. and Mackinnon, K. (1986) A review of the Afrotropical protected areas system. Cambridge, U.K.: International Union for Conservation of Nature and Natural Resources.

Päivinen, R. and Witt, R. (1989) The methodology development project for tropical forest cover assessment in West Africa. Nairobi: UNEP/GEMS/GRID.

Poore, D., Burgess, P., Palmer, J., Rietbergen, S. and Synnott, T. (1989) No timber without trees: sustainability in the tropical forest. London: Earthscan.

Short, L. S. and Horne, J. F. M. (1985) Behavioral notes on the nest parasitic Afrotropical honeyguides. Amer. Mus. Novit. 2825.

Taylor, M. (1988) The White-breasted Guineafowl in south-east Liberia. Unpublished report to World Pheasant Association and Royal Ontario Museum.

Taylor, M. J. (ms) Notes on observations of birds in Ghana. January-April 1988.

Thiollay, J.-M. (1985a) The birds of Ivory Coast: status and distribution. Malimbus 7: 1-59.

Thiollay, J.-M. (1985b) The West African forest avifauna: a review. Pp. 171-186 in A. W. Diamond and T. E. Lovejoy, eds. Conservation of tropical forest birds. Cambridge, U.K.: International Council for Bird Preservation (Techn. Publ. 4).

Thompson, H. (1990) Breeding biology, ecology and conservation of the White-necked Picathartes in the Gola and Peninsular forests, Sierra Leone. Preliminary report on a survey of breeding sites in the Western Area Peninsular Forests. Unpublished report to RSPB/ICBP.

WCMC/IUCN $=$ World Conservation Monitoring Centre/International Union for Conservation of Nature and Natural Resources (in prep.) Conservation atlas of tropical forest: Africa.

White, F. (1983) The vegetation of Africa. A descriptive memoir to accompany the UNESCO/ AETFAT/UNSO vegetation map of Africa. Paris: United Nations Education, Scientific and Cultural Organization.

\section{Acknowledgements}

This work is a result of discussions with Lincoln Fishpool, Malcolm Ausden, Peter Hayman, Peter Wood, Peter Robertson, Glyn Davies and Mary Gartshore; Mary Gartshore made available a large body of unpublished information for which I am especially 
grateful. Sally Wilson, Phil Marshall, Guy Dutson, Julian Branscombe, Roger Wilson, Wulf Gatter, M. E. J. Gore and particularly Simon Anstey also contributed useful information and comments.

\section{GARY ALLPORT}

International Council for Bird Preservation, 32 Cambridge Road, Girton, Cambridge CB3 oPJ. 